\title{
Reversed Polarity Episode in the Late Brunhes Epoch as Confirmed on Parallel Sections of Pleistocene Deposits in the Kinki District, Central Japan
}

\author{
Akira HAYASHIDA* \\ Department of Geology and Mineralogy, Kyoto University, Kyoto, Japan
}

(Received January 4, 1982; Revised June 12, 1984)

\begin{abstract}
Detailed paleomagnetic studies have been carried out on two sections of the Pleistocene sediments in the Kinki district, central Japan: the Takashima Formation exposed on the northwest coast of Lake Biwa, and the terrace forming deposits distributed in the northern area of Akashi City, about $150 \mathrm{~km}$ west of Lake Biwa. While these strata are assigned to the late Brunhes normal epoch, reversed polarity zones are observed in both sections. Based on correlation of volcanic ash layers intercalated in the sections, these reversed polarity zones are identified as the records of a reversed polarity episode, the Biwa I 'event', which was previously reported from a 200 -m-long core sample from Lake Biwa. This result confirms occurrence of a fully reversed geomagnetic field in the late Brunhes Epoch at least in central Japan. The Biwa I episode is possibly correlated to the Jamaica 'event' known from several deep-sea cores, and then the episode is suggested to be a global geomagnetic phenomenon in the late Brunhes epoch.
\end{abstract}

\section{Introduction}

Evidence for short-term fluctuations of the geomagnetic field direction has been reported based on paleomagnetic investigations of the middle Pleistocene to Holocene sediments (e.g., VEROSUB and BANERJEE, 1977). If these geomagnetic polarity episodes really occurred in the Brunhes normal epoch, they are expected to provide important information on the nature of geomagnetism, and to be utilized in the Quaternary researches as time markers or keys for stratigraphic correlations. At present, however, our knowledge on the short-term polarity episodes is far from establishing their status in the geomagnetic field history during the Brunhes epoch. Ages and durations of most of the proposed polarity episodes are still uncertain. A real coverage of the geomagnetic fluctuations during the episodes is also unknown, so that it is not clarified yet whether the short episodes are due to reversal of the main dipole field or just to non-dipole field activity. In consequence, the present status of the short polarity episodes in the Brunhes epoch is indefinite comparing with polarity epochs or events in a con-

\footnotetext{
*Now at Department of Earth Sciences, Doshisha University, Kyoto, Japan.
} 
ventional paleomagnetic polarity time scale.

Another, and probably more critical problem about polarity episodes in the Brunhes epoch arises on the quality of their paleomagnetic data. VEROSUB and BANERJEE (1977) pointed out that some paleomagnetic data which was presented to propose occurrence of polarity episodes is not well publicized and that further confirmation is required. For example, evidence for short polarity episodes were often obtained from subaqueous or underground sediments recovered by coring operations. In such cases, samples might be subjected to a risk of distortion during the coring procedure. Natural deformation of sediments caused by sliding or slumping is also difficult to evaluate on the core samples (VEROSUB, 1975). Thus, in order to establish occurrence of a short-term polarity episode, it is necessary to obtain consistent paleomagnetic data from a sampling site repeatedly and further from other sites distributed over a wide area. Then, more suitably, the data is desired to be obtained from parallel sections of exposed strata on land, where we can keep the chance of sample distortion to much less than in core sediments.

KAWAI et al. (1972) made a paleomagnetic study on a 200 -m-long sediment core from Lake Biwa, central Japan, and found occurrence of negative inclinations of remanent magnetization at five horizons in the core. Then, accompanying declination changes of about 180 degrees, three of the five horizons were claimed to have recorded reversed polarity 'events' during the Brunhes normal epoch. The reversed polarity zone at about $55 \mathrm{~m}$ deep was assigned to the Blake 'event' of about 0.11 Ma (SMITH and FosTER, 1969). The other two at about $85 \mathrm{~m}$ and $130 \mathrm{~m}$ deep were newly named the Biwa I and Biwa II 'events', respectively, and their ages were estimated at $0.18 \mathrm{Ma}$ and $0.29 \mathrm{Ma}$, based on extrapolation of three ${ }^{14} \mathrm{C}$ dates and the age of the Blake episode (YASKAWA, 1973). Reversely magnetized materials which are dated at about $0.1 \mathrm{Ma}$ and correlated to the Blake episode are known at several localities in the world (e.g., DENHAM et al., 1977; CREER et al., 1980; SASAJIMA et al., 1980). Reversed polarity episodes older than the Blake episode, however, have been rarely reported. Therefore, occurrence of the pre-Blake episodes, such as the Biwa I and Biwa II, has required further confirmation.

The 200-m core from Lake Biwa is stratigraphically correlated with the Osaka Group and the Kobiwako Group, which are distributed around Lake Biwa and the Osaka Bay in the Kinki district. Some volcanic ashes in the 200-m core were shown to be correlative with those found in land sections of the Osaka Group or the Kobiwako Group, based on physical and chemical properties of the ashes, such as heavy mineral composition, shape of glass shards, and thermomagnetic curves for ferromagnetic minerals (YoKoYAma, 1975; YoKoYAMA et al., 1980). Fortunately, the reversed polarity zone of the Biwa I episode contains a few volcanic ashes. The volcanic ash at about $82 \mathrm{~m}$ deep, called BB195, was a characteristic ash containing hornblende crystals and pumice grains (YoKOYAMA, 1975), and was dated at $0.17 \mathrm{Ma}$ by fission track method (NISHIMURA and YoKoYAMA, 1975). The ash at about $88 \mathrm{~m}$, which is called BB207, contained 
clinopyroxene, orthopyroxene and hornblende crystals (YoKoYAMA, 1975). YoKOYAMA et al. (1980) showed that the two volcanic ashes are correlative to those found in outcrops on land; BB195 and BB207 were respectively correlated to the Akatsuki and Taihoji volcanic ashes in the Takashima Formation, the uppermost Kobiwako Group exposed on the northwest coast of Lake Biwa. BB195 was correlated also to the Zatodani volcanic ash, which is intercalated in the uppermost Osaka Group forming the "higher terrace" at the north of Akashi City.

Figure 2 shows a summary of the tephrostratigraphic correlation between the 200-m core, the Takashima Formation and the "higher terrace" deposits in the Akashi area. We report here paleomagnetic data from the two sections on land, which are correlative to the horizon of the Biwa I episode. The results from the parallel sections confirm occurrence of the reversed polarity episode at least in central Japan.

\section{Paleomagnetism of the Takashima Formation}

\subsection{Geological setting and sampling}

The Takashima Formation is the uppermost part of the Kobiwako Group, distributed in the Aibano Hills on the northwest coast of Lake Biwa (Fig. 1). Stratigraphic outline of the Takashima Formation was described by YоконAMA et al. (1979), who divided it into four members: Shiratsuchidani Bed, Inokuchi Gravel Bed, Akatsukikaido Sandy Bed, and Shimokoga Gravel Bed, in ascending order. Lithology of these strata suggests that they deposited in a marginal environment of Laka Biwa. The Takashima Formation was implied to be assigned to the Brunhes epoch, based on normal magnetization of the Shiratsuchidani volcanic ash and on evidence of plant fossils (YoKOYAMA et al., 1977).

Samples for magnetic measurements were collected from four sections of the Akatsukikaido Bed, located at the southeast corner of the Aibano Hills. The geologic columnar sections and sampling borizons are shown in Fig. 3(a). The surveyed sections contain a key bed, the Taihoji volcanic ash, which was correlated to the ash BB207 of the 200-m core from Lake Biwa (YoKoYAMA et al., 1980; Fig. 2). The Akatsuki volcanic ash was previously observed at two localities near the present sampling sites (YoKOYAMA, 1969), and correlated to the ash BB195 of the 200-m core (YoKOYAMA et al., 1980; Fig. 2). The outcrops of the Akatsuki volcanic ash, however, are lost at present. Although its horizon is probably enclosed within the range of the columns in Fig. 3(a), the ash was not found around the sampling sites. The absence of the Akatsuki volcanic ash from the surveyed sections is probably explained by local erosion or no deposition of the ash due to the fluvial nature of the Takashima Formation.

\subsection{Laboratory procedure}

The sample obtained from one horizon of the section comprised five or six specimens. Each specimen was mounted in a plastic case of $2 \mathrm{~cm}$ cube. Remanent magnetization of the specimen was measured on a spinner magnetometer 


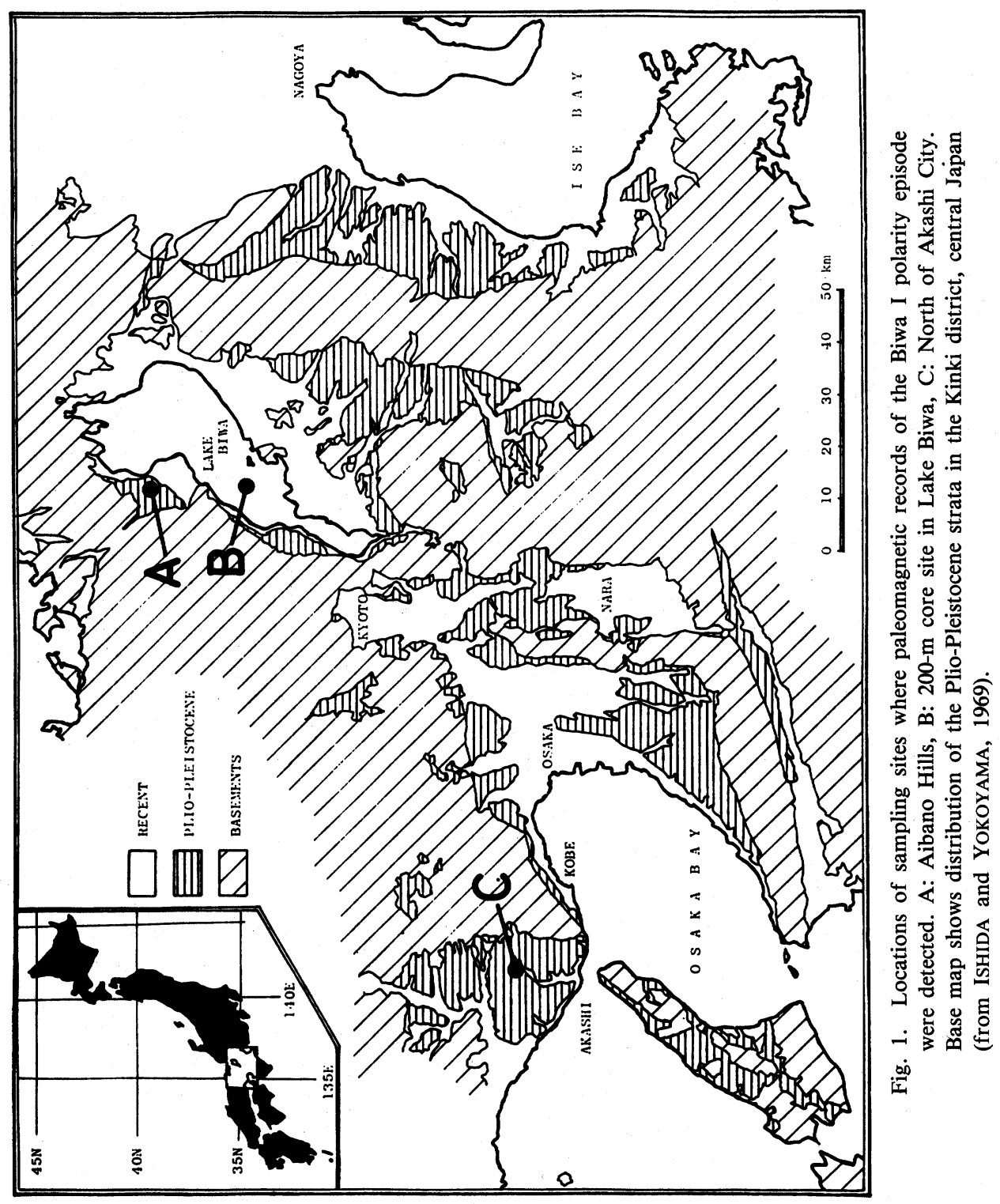




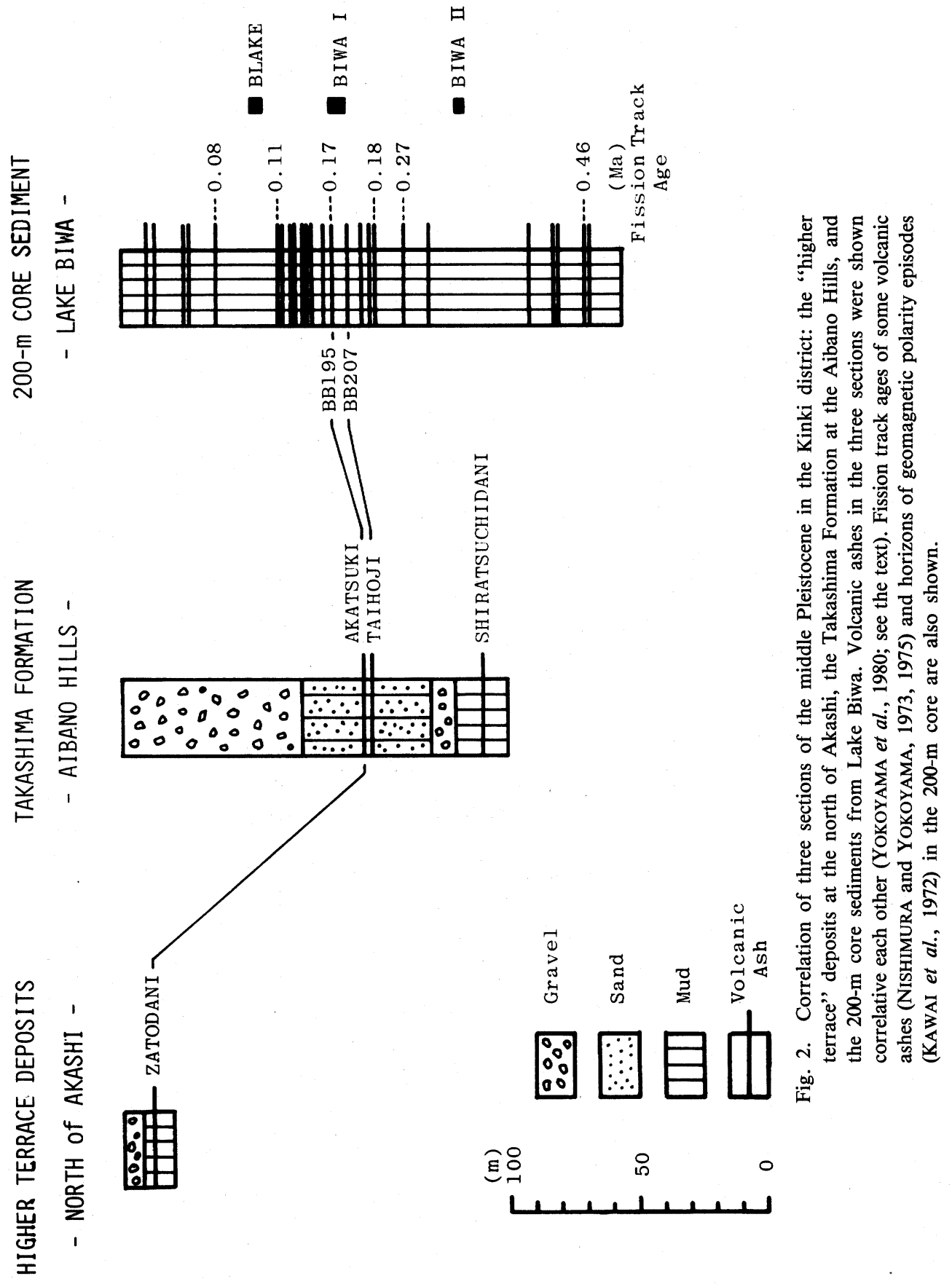




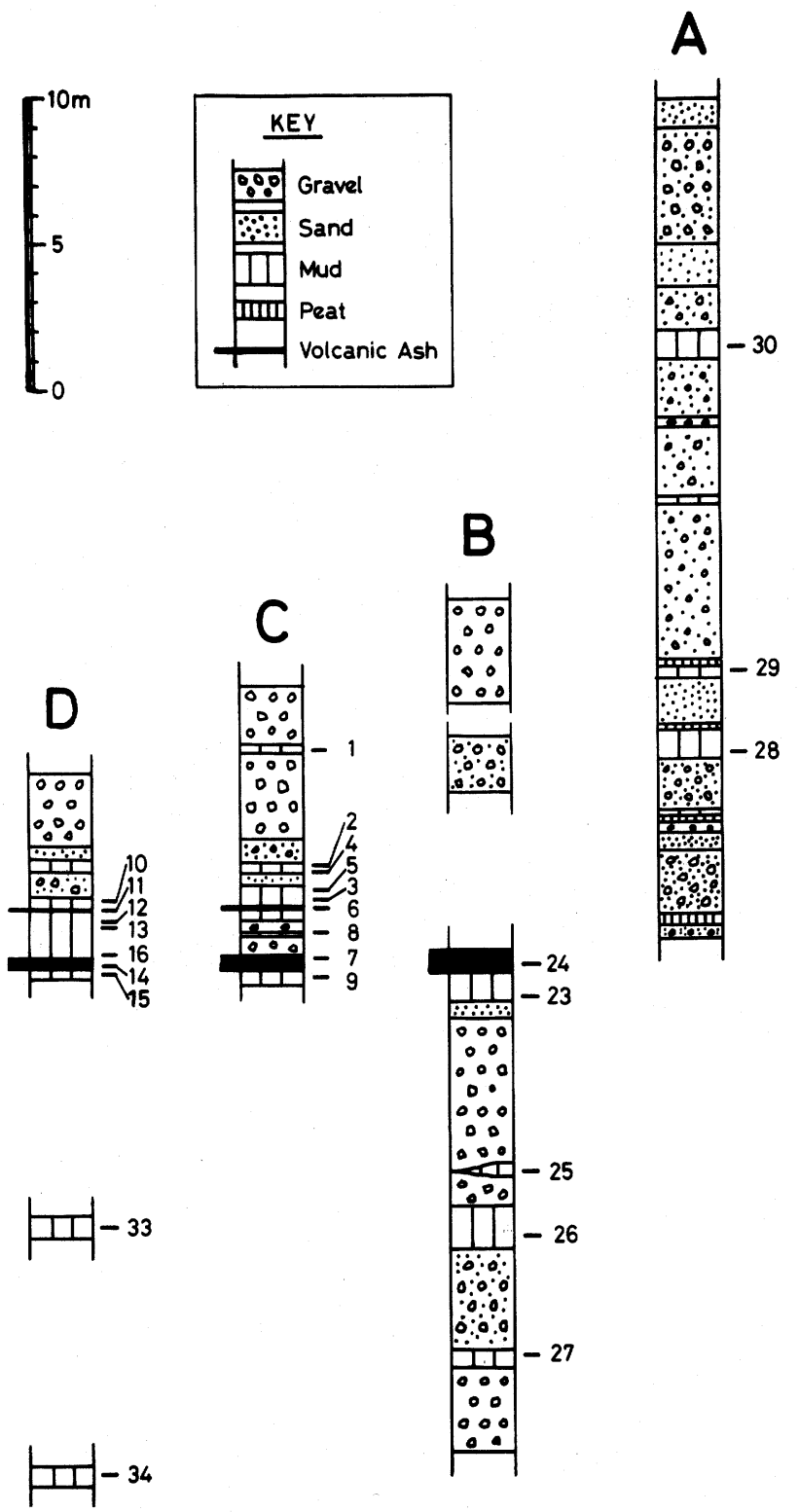

(a)

Fig. 3(a). Columnar sections of the Akatsuki-kaido bed of the Takashima Formation at sampling sites (A to D) in the Aibano Hills, and stratigraphic horizons of paleomagnetic samples. (b) Plot of mean declinations, mean inclination and latitudes of VGP's. Samples which had too 


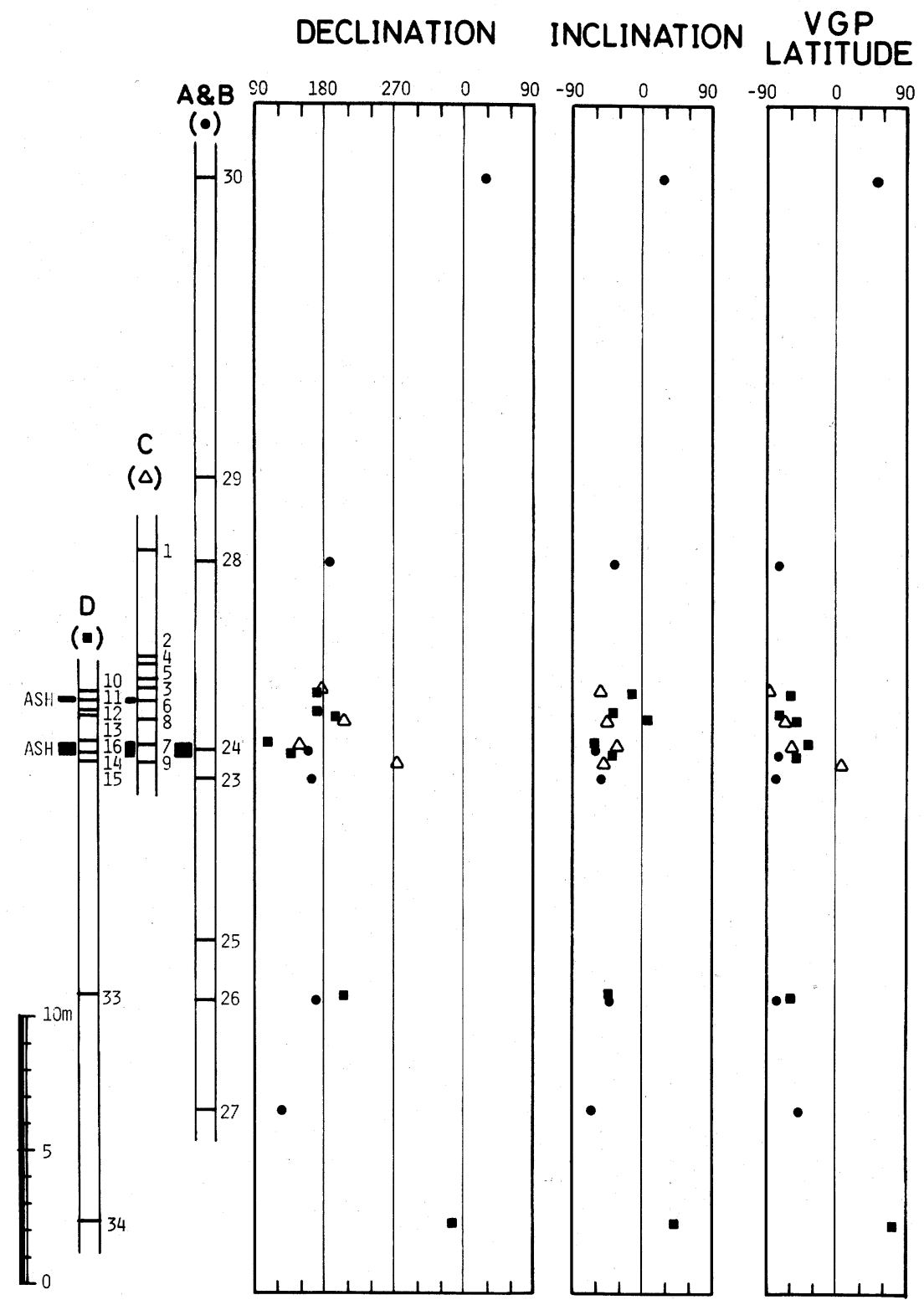

(b)

weak magnetization or scattered directions were excluded. Numbers show the sample names corresponding to those in Table 1 and Fig. 4. 

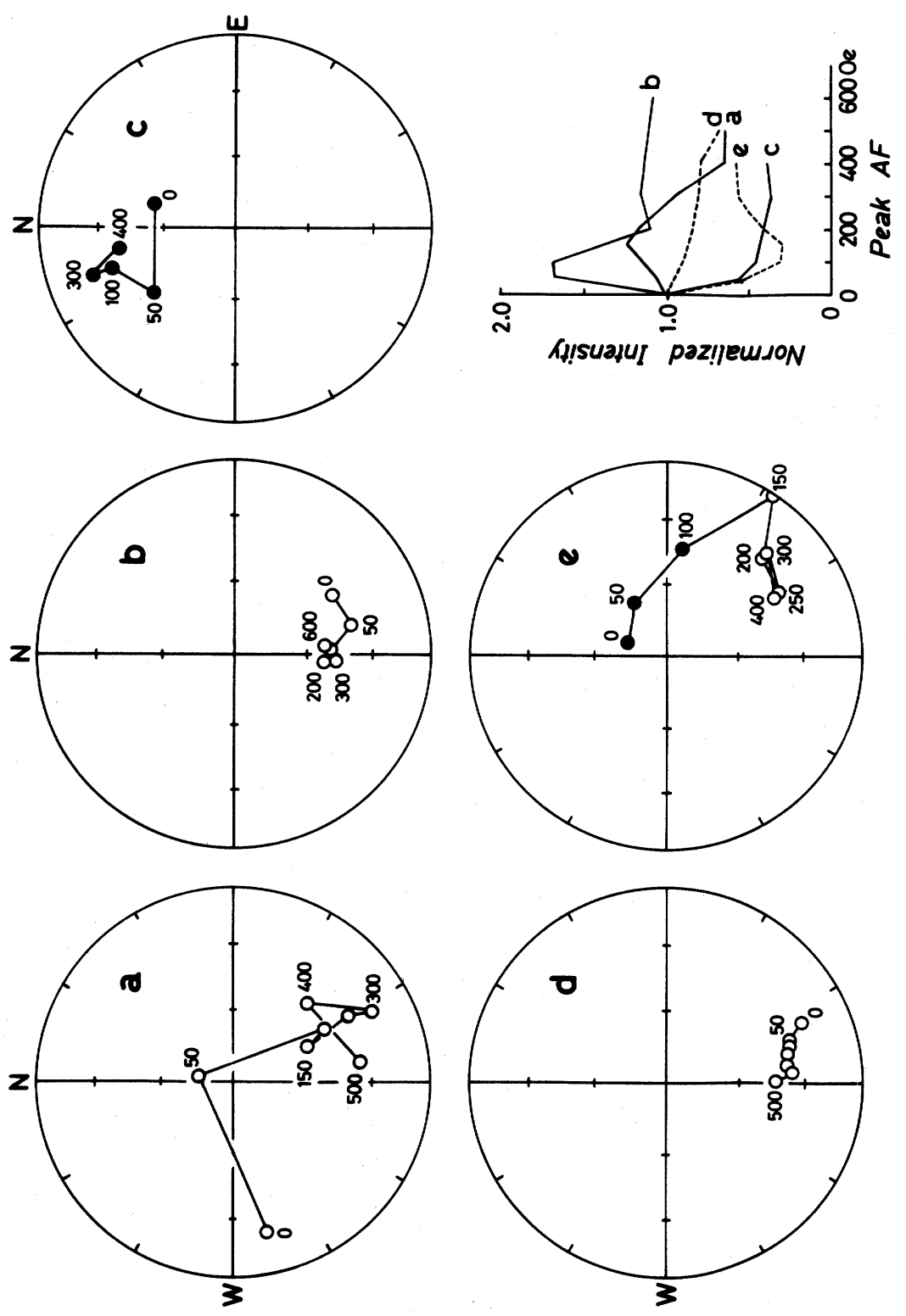


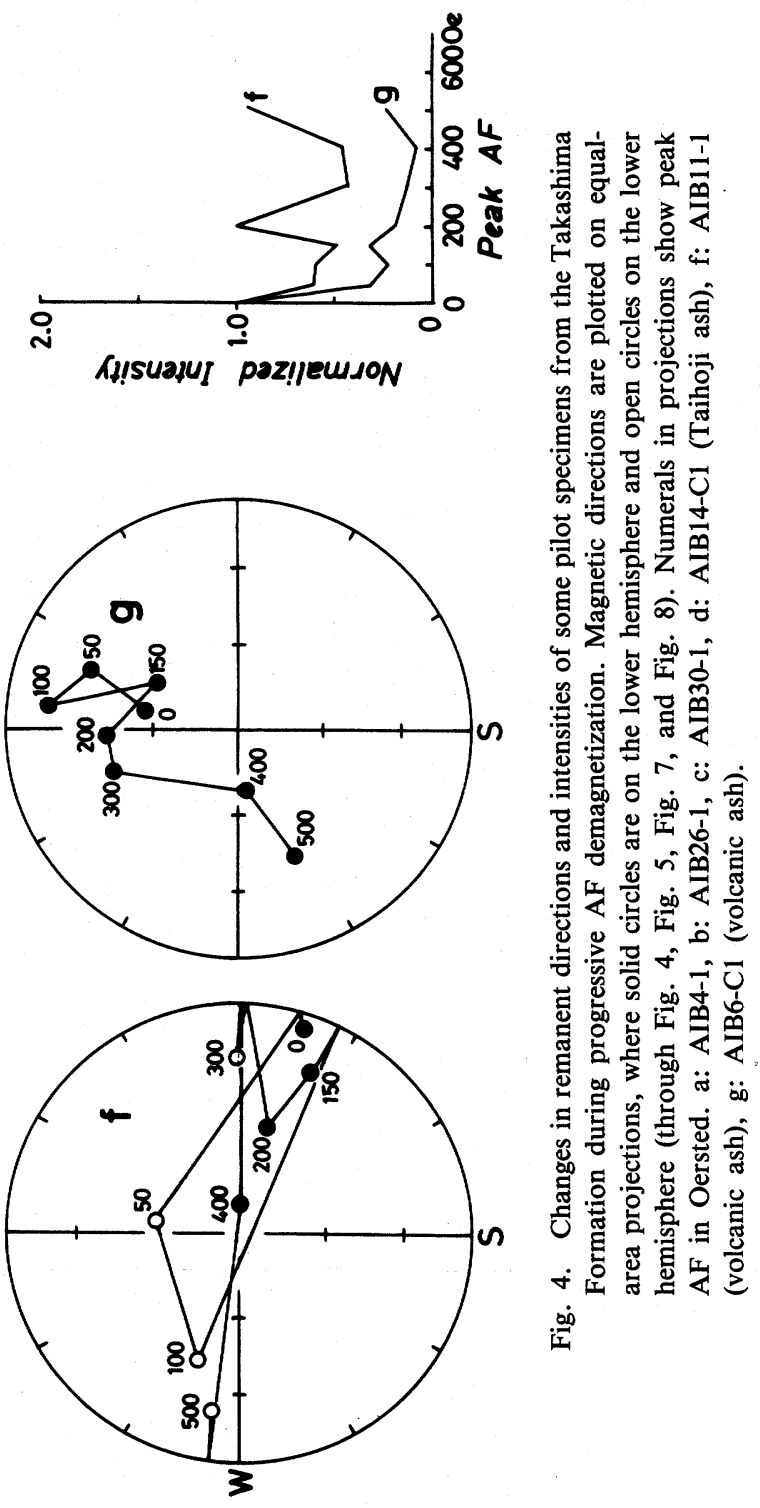


(Schonstedt's Type SSM-1A). Magnetic directions were corrected for the azimuth and dip of field orientations. Because the strata dip less than three degrees at the sampling sites, the magnetic directions were not corrected for the tilt of the strata.

One or two specimens from each horizon were subjected to progressive alternating field (AF) demagnetization tests. Figure 4 shows typical examples of changes in remanent direction and intensity during the progressive demagnetization. The remanent magnetization of most specimens were stable in response to AF demagnetization. Some specimens, however, showed significant changes in magnetic direction and intensity after the AF treatments in peak AF of $100 \mathrm{Oe}$ or $200 \mathrm{Oe}$ (Fig. 4). In these cases, the remanent directions tended to move systematically towards reversed polarity directions. The magnetic component reduced by the AF demagnetization is interpreted as a secondary overprint, which was probably originated from viscous remanent magnetization (VRM). Pilot specimens of the two samples, AIB6 and AIB11, taken from a volcanic ash showed extraordinarily confused trails of remanent directions through progressive AF demagnetization (Fig. 4). This volcanic ash seems unsuitable for a paleomagnetic work because of the instability of remanent magnetization. The other volcanic ash layer, the Taihoji volcanic ash, had quite stable magnetization.

Remanent magnetization of other specimens were routinely measured after AF demagnetization in peak fields of 100 Oe and 200 Oe. Magnetization of a few samples were not measured, for their intensity were less than or comparable to the noise level of our measuring instrumentation (about $1 \times 10^{-7}$ $\mathrm{emu} / \mathrm{cm}^{3}$ ). Mean direction of remanent magnetization and precision parameters of the other samples were calculated for each treatment of the AF demagnetizations using the Fisherian statistics (FISHER, 1953). The more clustered magnetic directions among the results of the two AF treatments was adopted as a mean direction of each horizon.

\subsection{Results}

The mean declination, mean inclination, precision parameters, and position of virtual geomagnetic pole (VGP) are listed in Table 1. Remanent directions of some horizons, including a volcanic ash (AIB6 and AIB11), are so scattered as to give the precision parameter $(k)$ less than 3 . The other samples showed significant clustering of remanent directions, and their magnetic polarities were possible to be clarified into normal or reversed ones. In Fig. 3(b), mean declinations, mean inclinations, and latitudes of VGP positions of these samples are plotted in respect to their stratigraphic positions. The mean magnetic directions and VGP positions are also plotted on equal-area projections in Fig. 5. As shown in these diagrams, most of the samples from the surveyed sections were magnetized in reversed polarity, and normal polarity data was obtained only from the horizons at the bottom and top of the section. Thus a reversed polarity zone, of which thickness is estimated to exceed $20 \mathrm{~m}$, was identified in the Takashima Formation. 
Table 1. Results of magnetic measurement of samples from the Takashima Formation in the Aibano Hills.

\begin{tabular}{lrrrrrrrrr}
\hline Sample & $H$ & $D$ & $I$ & $M$ & $N$ & $k$ & $A 95$ & Lat. & Lon. \\
\hline [Section A] & & & & & & & & & \\
AIB 30 & 100 & 28.8 & 26.5 & 0.1 & 4 & 4.6 & 47.5 & 51.9 & -109.2 \\
AIB 29 & 100 & 126.4 & -16.3 & 0.1 & 4 & 1.4 & - & - & - \\
AIB 8 & 100 & 187.5 & -33.5 & 0.3 & 4 & 6.4 & 39.4 & -71.8 & 112.6 \\
[Section B] & & & & & & & & & \\
AIB 24 (Ash) & 100 & 160.0 & -60.0 & 11.5 & 4 & 1128.5 & 2.7 & -73.3 & -108.1 \\
AIB 23 & 100 & 163.9 & -52.0 & 0.3 & 4 & 3.9 & 53.8 & -76.4 & -140.0 \\
AIB 26 & 100 & 170.4 & -40.7 & 0.7 & 4 & 103.3 & 9.1 & -75.4 & 173.6 \\
AIB 27 & 100 & 123.4 & -65.3 & 0.1 & 4 & 3.6 & 56.7 & -46.8 & -99.6 \\
[Section C] & & & & & & & & & \\
AIB 4 & 200 & 212.7 & -2.1 & 0.2 & 5 & 2.1 & - & - & - \\
AIB 3 & 200 & 177.1 & -54.1 & 0.4 & 5 & 5.9 & 34.5 & -87.5 & -148.8 \\
AIB 6 (Ash) & 100 & 320.6 & 12.5 & 0.6 & 8 & 2.5 & - & - & - \\
AIB 8 & 100 & 206.7 & -43.6 & 0.2 & 5 & 14.5 & 20.8 & -65.1 & 61.9 \\
AIB 7 (Ash) & 200 & 147.6 & -33.0 & 3.1 & 5 & 15.4 & 20.1 & -56.5 & -156.6 \\
AIB 9 & 200 & 277.3 & -50.8 & 0.2 & 3 & 10.1 & 40.9 & 8.4 & 0.6 \\
[Section D] & & & & & & & & & \\
AIB 10 & 100 & 169.2 & -13.5 & 0.8 & 5 & 13.7 & 21.4 & -59.9 & 157.8 \\
AIB 11 (Ash) & 200 & 83.5 & 17.4 & 3.6 & 10 & 1.7 & - & - & - \\
AIB 12 & 100 & 170.9 & -39.2 & 0.5 & 5 & 30.8 & 14.0 & -74.7 & 169.6 \\
AIB 13 & 100 & 195.7 & 4.8 & 0.2 & 4 & 14.6 & 24.9 & -49.5 & 111.4 \\
AIB 16 & 200 & 107.1 & -60.6 & 0.3 & 4 & 11.9 & 27.8 & -34.3 & -103.9 \\
AIB 14 (Ash) & 200 & 137.4 & -39.0 & 1.2 & 4 & 16.5 & 23.3 & -50.7 & -142.0 \\
AIB 33 & 100 & 217.2 & -43.9 & 0.2 & 4 & 4.9 & 46.1 & -56.8 & 52.2 \\
AIB 34 & 200 & 345.0 & 40.9 & 0.2 & 2 & 123.3 & 22.7 & 72.4 & 7.9 \\
\hline
\end{tabular}

$\boldsymbol{H}$ : peak field of alternating field demagnetization in Oersted.

$D$ and $I$ : mean declination and inclination in degrees east and downward, respectively.

$M$ : mean intensity of magnetization in $10^{-6} \mathrm{emu} / \mathrm{cm}^{3}$.

$N$ : number of specimens.

$k$ : precision parameter (FISHER, 1953).

$A_{95}$ : radius of $95 \%$ confidence circle in degrees.

Lat. and Lon.: latitude and longitude of virtual geomangetic pole in degrees north and east, respectively.

Note that estimation of the precision parameters, $k$ and $A_{95}$, are not reliable when the number of specimens are as small as 3 or 4.

\section{Paleomagnetism of the Higher Terrace Deposits}

\subsection{Geological setting}

In the Akashi and western Kobe area of the Kinki district, geomorphic surfaces are widely developed. The flat plane which is most widely distributed here is called the Meimi Surface, or the "higher terrace" of this region (ITIHARA and Oguro, 1958; ItIHARA et al., 1960). The Meimi Gravels, of which depositional surface is preserved as the Meimi Surface, was suggested to have been 

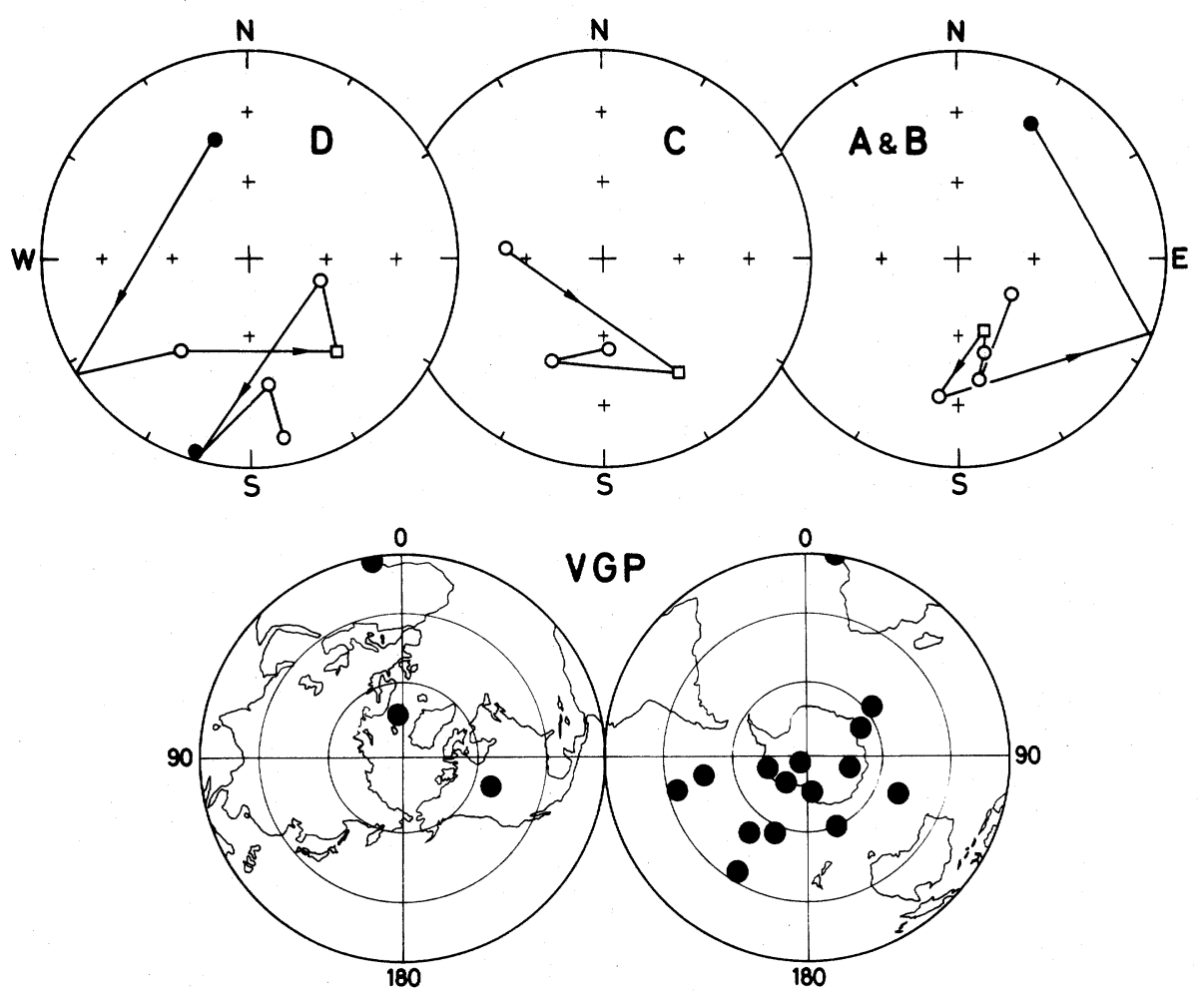

Fig. 5. Plots of mean directions of remanent magnetization of samples from sections $A$ to $D$ at the Aibano Hills (top), and position's of VGP's (bottom).

deposited on a flood plane or an alluvial fan during a period of a higher sea-level than the present (ITIHARA et al., 1960; KAwANA, 1973). The Meimi Gravels are inferred to be younger than the middle Pleistocene based on the fact that its depositional surface is well preserved. The younger geomorphic surface, which is called the Nishiyagi Surface or the "middle terrace" (ITIHARA et al., 1960), was suggested to be correlative to the Last Interglacial period, and then the Meimi Surface was assigned to the early interglacial time (ITIHARA, 1961; HuzitA et al., 1971; IsHIDA, 1970).

Recently, IsHIDA (1978) made a stratigraphic description of the outcrop excavated from the Meimi Surface at the north of Akashi City (Fig. 1). In this outcrop, the terrace deposits including fine-grained sediments are unconformably overlying more consolidated siltstones of the lower Osaka Group. The columnar section of the overlying terrace deposits is shown in Fig. 6. The topmost layer of the terrace deposits is the Meimi Gravels. The main part of the outcrop consists of sand and mud layers intercalating volcanic ash. The lower part has characteristic features in lithology which are commonly observed on marine clay 


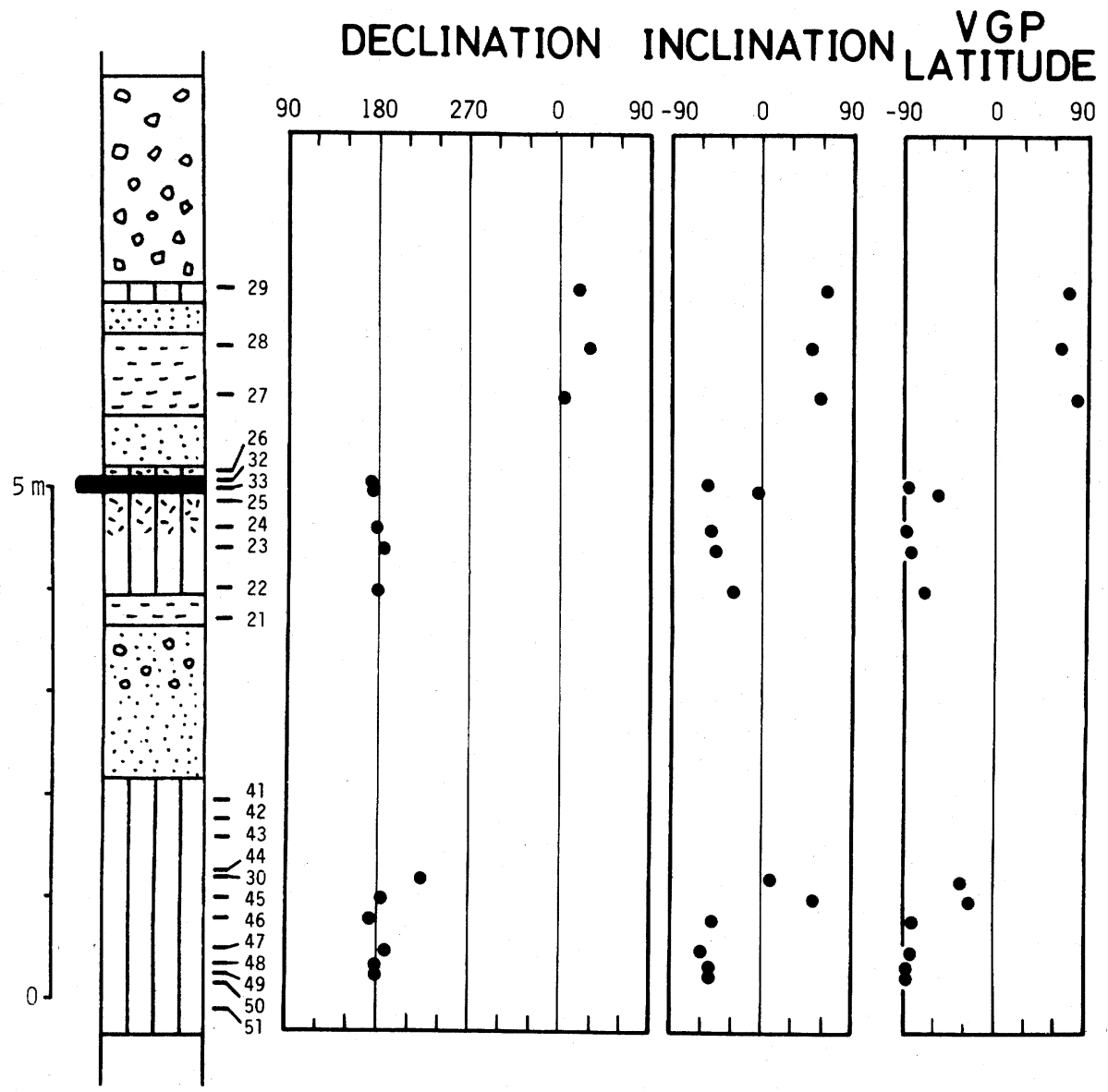

Fig. 6. Columnar section of the "higher terrace" deposits exposed at the north of Akashi City, horizons of paleomagnetic samples, and results of magnetic measurements. Numbers along the columnar section show sample names, corresponding to those in Table 2 and Fig. 7.

beds of the upper Osaka Group. IsHIDA (1978) suggested that this mud layer was accumulated during the transgression which formed the Meimi Surface. The volcanic ash layer intercalated in a peaty mud beneath the Meimi Gravels is called the Zatodani volcanic ash. This ash was correlated to the ash BB195 of the 200-m core from Lake Biwa, as well as the Akatsuki volcanic ash of the Takashima Formation (YoKoYAMA et al., 1980; Fig. 2). The Zatodani volcanic ash consists of the two layers; the lower part is abundant in hornblende crystals and pumice grains which are as coarse as fine sands, and upper part consists of fine grains of clay size. 


\subsection{Procedure}

Paleomagnetic study was carried out on samples collected from the outcrop of the terrace forming deposits described above. Horizons of the samples were shown in Fig. 6. Methods of sample preparation, magnetic measurements and demagnetization were the same as those used in the case of the Takashima Formation.

Figure 7 shows representative results of progressive AF demagnetization made on pilot specimens. While most of the specimens were revealed to have stable magnetization against AF demagnetization, abrupt changes in remanent direction were observed on a few specimens after the AF treatments of 300 Oe or 400 Oe peak fields. It is possible to interpret that the abrupt changes were due to the instrumental noise which exceeded low magnetic intensity for some specimens, or due to superimposed anhysteretic remanent magnetization (ARM) during the AF demagnetization process. A soft component of remanent magnetization, which was probably originated from VRM, seemed to be minimized by AF demagnetization in peak fields of 100 Oe or $200 \mathrm{Oe}$.

Other specimens were subjected to routine measurements after AF demagnetization in peak fields of 100 Oe and then of 200 Oe. The more clustered magnetic direction of the two results was selected as the mean direction of each horizon.

\subsection{Results}

The mean directions and precision parameters are listed in Table 2. Remanent directions of most samples showed significant clustering, while some samples had scattered directions giving the precision parameter $(k)$ less than 3 . Remanent magnetizations of the two samples, AK33 and AK32, which were respectively obtained from the lower and upper layers of the Zatodani volcanic ash, were very stable against AF demagnetization (Fig. 7). Although the declinations of the two samples were both in the southward directions, the inclinations were significantly different; AK32 from the lower part of the ash was magnetized in a nearly horizontal direction, and AK32 from the upper part upward about 50 degrees. This ash layer is supposed to be a still-water deposit accumulated within a short interval of time. Therefore, the magnetizations of the upper and lower layers are expected to have been acquired almost simultaneously. Because the upper layer is composed of much finer grains than the lower part, the upper sample, AK32, seems to represent the ancient geomagnetic field direction. The shallower inclination of AK33 consisting of coaser material may have been caused by an inclination error of remanence acquisition.

In Fig. 6, the mean directions of remanent magnetization and latitudes of VGP positions are plotted in respect to stratigraphic horizons of the samples. The lower to middle part of the section was indicated to be magnetized in reversed polarity, and the upper part was in normal polarity. The Zatodani volcanic ash is situated at the top of the reversed polarity zone. The lower boundary of the reversed zone was not detected within the exposed part of the section. Thus 

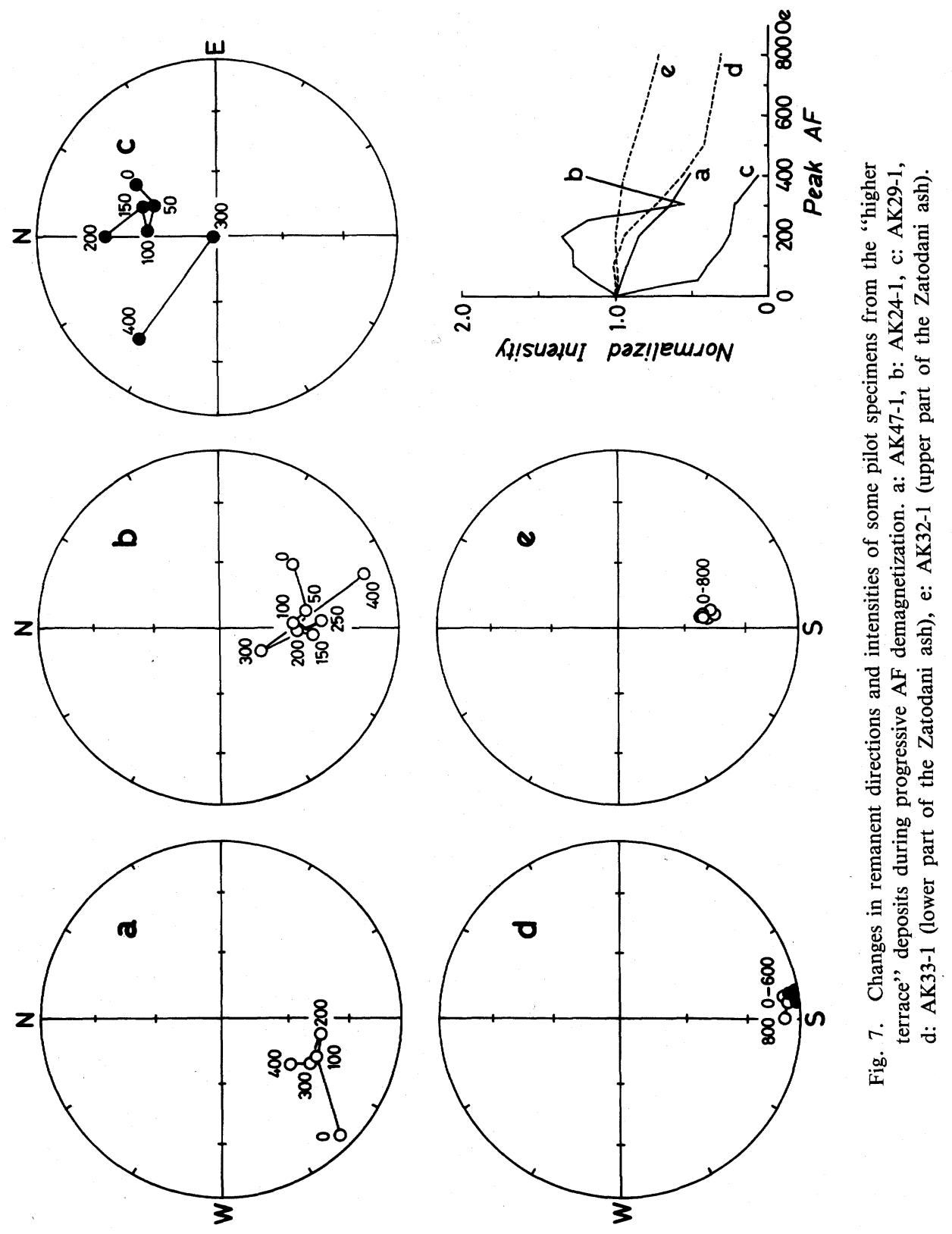
Table 2. Results of magnetic measurement of samples from the "higher terrace" deposits at the north of Akashi City.

\begin{tabular}{|c|c|c|c|c|c|c|c|c|c|}
\hline Sample & $\boldsymbol{H}$ & $D$ & $I$ & $M$ & $N$ & $k$ & $A_{95}$ & Lat. & Lon. \\
\hline AK 29 & 100 & 20.6 & 60.1 & 0.8 & 4 & 8.5 & 33.5 & 72.5 & -163.1 \\
\hline AK 28 & 100 & 29.7 & 49.6 & 0.9 & 3 & 15.9 & 32.0 & 64.7 & -134.2 \\
\hline AK 27 & 100 & 4.6 & 60.8 & 1.4 & 3 & 21.3 & 27.4 & 81.8 & 159.8 \\
\hline AK 26 & 100 & 20.4 & 44.6 & 0.7 & 4 & 1.7 & - & - & - \\
\hline AK 32 (Ash) & 200 & 174.8 & -52.7 & 1.9 & 4 & 346.5 & 4.9 & -85.5 & -148.7 \\
\hline AK 33 (Ash) & 100 & 171.9 & -1.6 & 15.0 & 3 & 32.7 & 21.9 & -55.5 & 149.4 \\
\hline AK 25 & 200 & 194.9 & -64.5 & 0.3 & 4 & 2.8 & - & - & - \\
\hline AK 24 & 100 & 178.6 & -51.3 & 1.9 & 3 & 20.6 & 27.9 & -87.3 & 160.7 \\
\hline AK 23 & 100 & 172.4 & -54.6 & 0.6 & 4 & 11.1 & 28.8 & -83.7 & -126.6 \\
\hline AK 22 & 100 & 178.2 & -25.7 & 0.4 & 3 & 6.4 & 53.3 & -69.0 & 139.9 \\
\hline AK 21 & 200 & 128.2 & 14.9 & 0.9 & 3 & 2.0 & - & - & - \\
\hline AK 41 & 200 & 185.2 & 23.9 & 0.2 & 4 & 1.2 & - & - & - \\
\hline AK 42 & 200 & 309.8 & 10.6 & 0.5 & 4 & 1.4 & - & - & - \\
\hline AK 43 & 200 & 219.2 & -60.8 & 0.2 & 4 & 2.4 & - & - & - \\
\hline AK 44 & 200 & 185.3 & 46.5 & 0.6 & 4 & 1.4 & - & - & - \\
\hline AK 45 & 200 & 185.7 & 52.6 & 0.6 & 4 & 10.7 & 29.5 & -22.2 & 129.9 \\
\hline AK 46 & 200 & 168.0 & -47.7 & 0.4 & 4 & 13.7 & 25.7 & -78.3 & -160.7 \\
\hline AK 47 & 200 & 188.9 & -58.6 & 0.3 & 4 & 26.5 & 18.2 & -81.4 & 8.0 \\
\hline AK 48 & 200 & 179.9 & -49.8 & 0.2 & 4 & 4.8 & 47.0 & -86.2 & 136.3 \\
\hline AK 49 & 200 & 179.4 & -50.2 & 0.2 & 4 & 17.5 & 22.6 & -86.5 & 143.4 \\
\hline AK 50 & 200 & 213.9 & 37.9 & 4.8 & 4 & 1.1 & - & - & - \\
\hline AK 51 & 200 & 118.1 & -18.8 & 1.2 & 4 & 2.3 & - & - & - \\
\hline
\end{tabular}

See Table 1 for explanation.

the thickness of the reversed polarity zone is estimated more than $6 \mathrm{~m}$. Plots of the directions of remanent magnetization and positions of the VGP are shown on equal-area projections in Fig. 8.

\section{Discussion}

\subsection{Confirmation of the Biwa I episode}

It has been shown that reversely magnetized zones exist in the Takashima Formation of the Kobiwako Group on the northwest coast of Lake Biwa, and in the uppermost Osaka Group forming the "higher terrace" in the northern area of Akashi City. In both areas, samples were collected from the outcrops, where the sediments appeared to have suffered neither weathering nor mechanical deformation. Remanent magnetization of the samples were well examined by AF demagnetization tests. Thus it is reasonably accepted that the remanent magnetization shows direction of the geomagnetic field at the time of initial deposition and subsequent compaction of the sediments. As mentioned before, the volcanic ash layers included in both sections were correlated to the ashes BB207 and BB195 (YoKOYAMA et al., 1980), which occurred on the horizon of the Biwa I 'event' in the 200-m core from Lake Biwa (KAWAI et al., 1972). Therefore, 

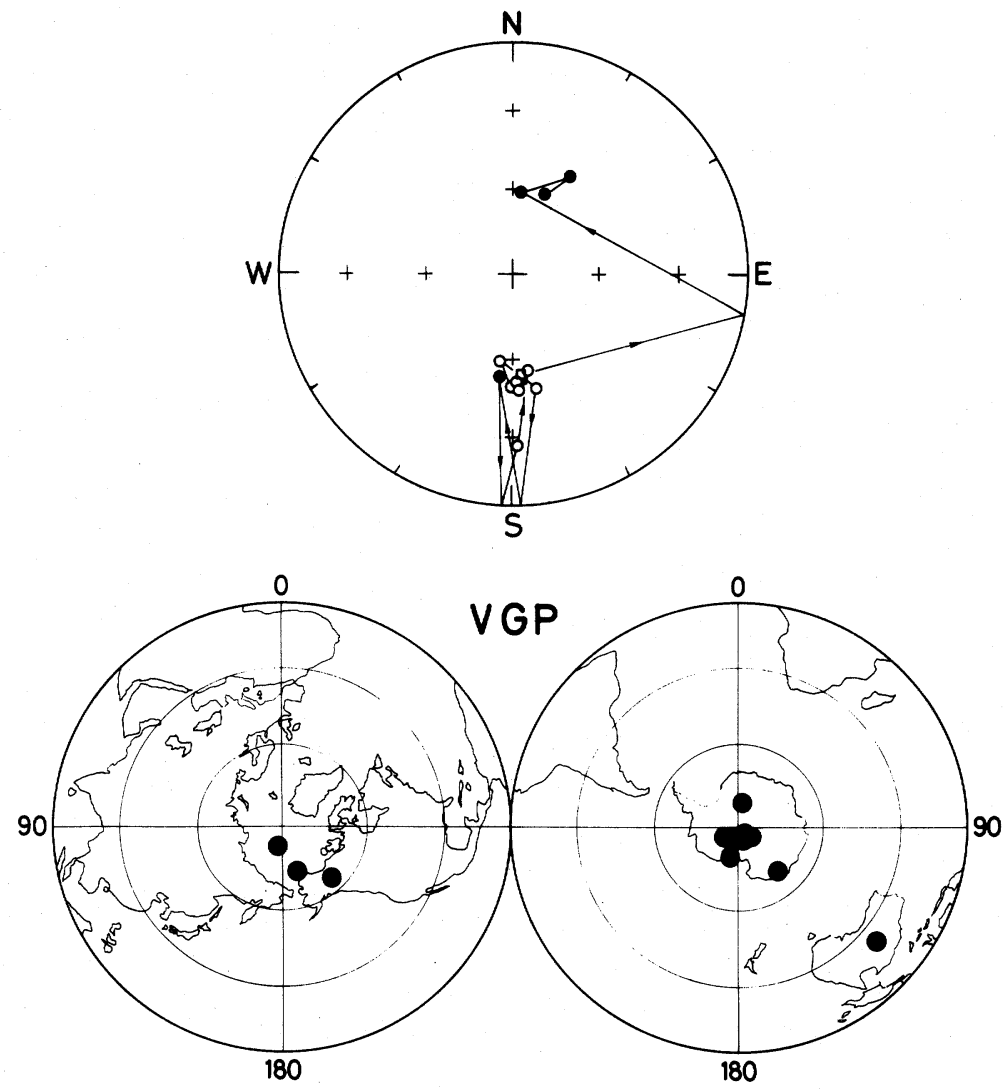

Fig. 8. Plots of mean directions of remanent magnetization of samples from the "higher terrace" deposits at the north of Akashi City (top), and positions of VGP's (bottom).

the reversed polarity zones found in the present study are recognized to be records of a reversed polarity episode during the Brunhes epoch.

The correlation of the Taihoji, Akatsuki and Zatodani volcanic ashes with BB207 and BB195 mentioned above is the most favorable one to the best of tephrostratigraphic knowledge on the Plio-Pleistocene in the Kinki district. It may be faithful to say, however, that the correlation is not proved definitely. There remains a possibility that volcanic ashes in the Takashima Formation and in the terrace deposits at the north of Akashi might be correlated to other volcanic ashes similar to BB195 and BB207. If this is the case, the assignment of the reversed polarity zones to the Biwa I episode would be a failure; they might be allocated to the Matuyama reversed epoch, as would be concluded in conventional magnetostratigraphy.

It seems inappropriate, however, to assign the Takashima Formation and the terrace deposits at the north of Akashi to the Matuyama epoch or older 
periods, in view of the stratigraphic framework of the Plio-Pleistocene Series in the Kinki district. Although detailed magnetostratigraphic work and radiometric dating have not been carried out on the uppermost part of the Osaka and Kobiwako group on land, age of the Takashima Formation and the "higher terrace" deposits at the north of Akashi is generally believed as younger than the middle Pleistocene. Grounds for this estimation are summarized as follows: (1) The Shiratsuchidani volcanic ash in the lower part of the Takashima Formation was shown to be magnetized in normal polarity and suggested to be included in the Brunhes epoch (YoKoyama et al., 1977). (2) Elements of Metasequoia flora (ITIHARA, 1961), which has been extinct since the end of the Matuyama epoch (MAENAKA et al., 1977), were not found both from the Takashima Formation (YoKOYAMA et al., 1977) and from the "higher terrace" deposits at the north of Akashi (IsHIDA, 1978). (3) Consolidation of mud layers in both areas are much less than those of the lower to middle part of the Osaka and Kobiwako groups. (4) The depositional surface of the Meimi Gravels is well preserved as a geomorphic flat plane (ITIHARA and OGURO, 1958; ItIHARA et al., 1960; KAWANA, 1973). These facts, (1) to (4), suggest that the Takashima Formation and the "higher terrace" deposits at the north of Akashi were deposited in the middle or late Pleistocene, that is, in the Brunhes epoch. Then it is most probable that these strata are correlated to some horizon of the 200-m core from Lake Biwa, which covers the period of this $0.5 \mathrm{~m}$.y. (NISHIMURA and YoKOYAMA, 1973 and 1975). Among the volcanic ashes of the 200-m core, only BB207 and BB195 can be assigned to the Taihoji volcanic ash and the Akatsuki volcanic ash of the Takashima Formation, respectively, and only BB195 can be correlated to the Zatodani volcanic ash in the "higher terrace" deposits (YoKoYAMA et al., 1980). Thus, at present, the correlation of the reversed polarity zones found in the present study to the Biwa I polarity episode is accepted as the most reasonable interpretation.

Figure 9 shows the correlation of the surveyed sections of the Takashima Formation and the terrace deposits at the north of Akashi with the horizon of the Biwa I episode of the 200-m core from Lake Biwa. As shown in the figure, the reversed polarity zones occur on concordant horizons of each section in respect to the tephrostratigraphic data. The sampling sites of the Takashima Formation are located about $16 \mathrm{~km}$ apart from the $200-\mathrm{m}$ core site in Lake Biwa, and the site at the north of Akashi is about $150 \mathrm{~km}$ apart from the Lake (Fig. 1). Sedimentary environment in each area was different as represented by a variety of lithology. The concordant paleomagnetic results obtained from these three areas strongly suggest real existence of the Biwa I episode. Thus, occurrence of a reversed polarity episode in the Brunhes normal epoch was confirmed by the study of the parallel sections.

VGP positions obtained from the Biwa I reversed polarity zones both in the Takashima Formation and at the north of Akashi are plotted on the high latitude area of the Southern Hemisphere (Fig. 5 and Fig. 8). It is shown that the geomagnetic field during the episode was genuinely reversed at least in the 


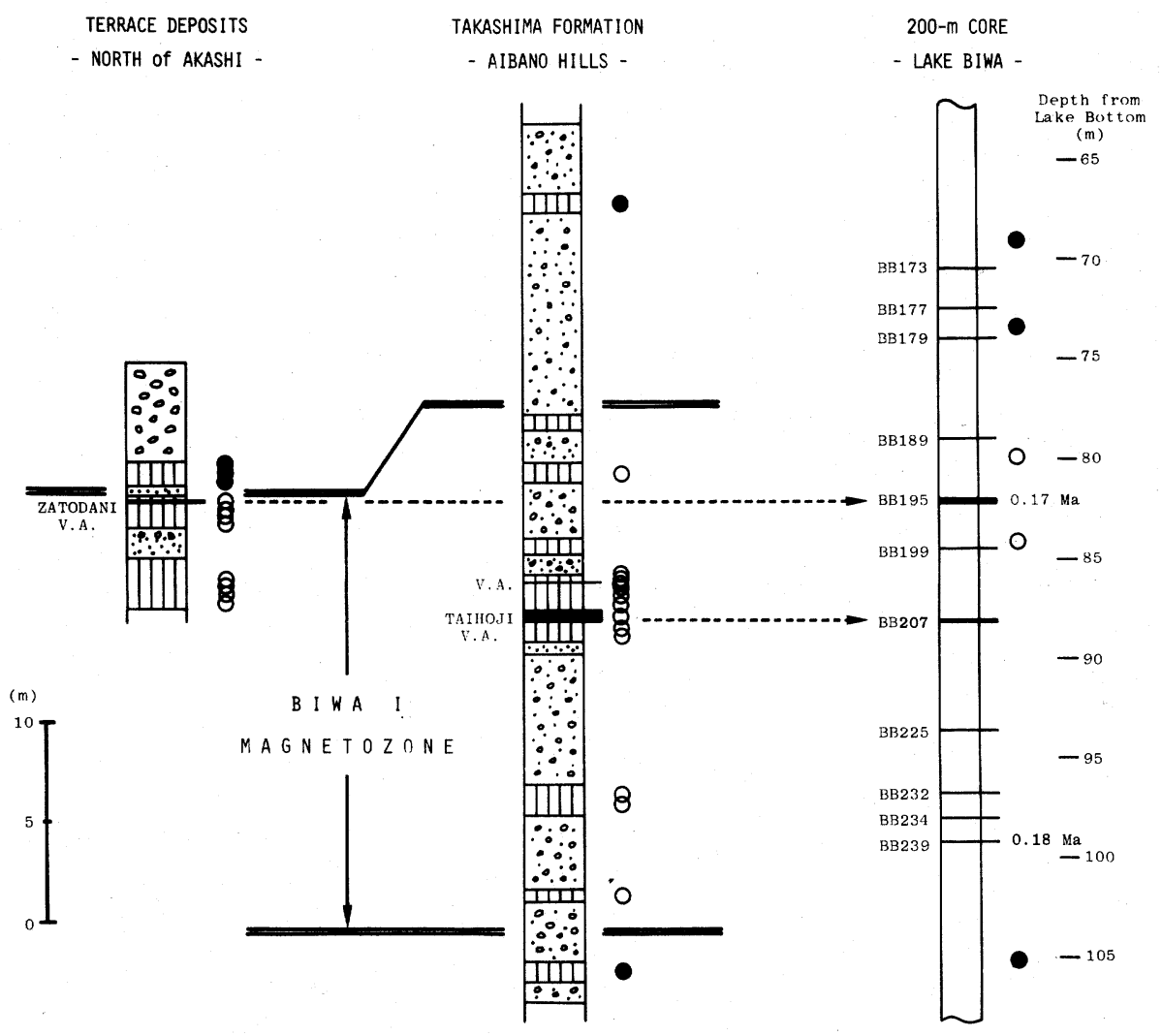

Fig. 9. Tephrostratigraphic and magnetostratigraphic correlation of the 200-m core from Lake Biwa, the Takashima Formation at the Aibano Hills, and the "higher terrace" deposits at the north of Akashi City. Closed and open circles show normal and reversed polarities of remanent magnetization, respectively. Fission track ages of two volcanic ashes in the $200-\mathrm{m}$ core are also shown.

Kinki district of central Japan. It is also suggested that the geomagnetic field direction was once locked in reversed polarity for a certain time interval. Thus the Biwa I episode resembles a polarity event rather than an excursion of the pole from normal polarity, or an anomalous fluctuation of geomagnetic field.

\subsection{Comparison with deep-sea core data}

While the present results suggest that a reversed polarity episode occurred prior to the Blake episode at least in central Japan, its reality as a global geomagnetic polarity phenomenon has remained unsolved. Reliable paleomagnetic records of reversed polarity episodes older than the Blake episode have been sparsely reported from other areas of the world. Among the available data, anomalous paleomagnetic features in some deep-sea core sediments reported by Wollin et al. (1971), Denham (1976), and Denham et al. (1977) are candidates 
which may represent the same geomagnetic phenomenon as the Biwa I episode. In this section, we made a discussion about possibility of world-wide correlation of the Biwa I episode, especially from a climatostratigraphical view point.

Wollin et al. (1971) found anomalous inclinations of remanent magnetization on several horizons in the Brunhes-age sediments of three deep-sea cores: RC9-181 from the Mediterranean, V12-122 from the Caribbean, and V20-108 from the North Pacific Ocean. The horizon dated about $0.11 \mathrm{Ma}$ was assigned to the Blake episode, and the older episodes were named the 'Jamaica event', 'Levantine event', and 'Emperor event', in descending order, by RYAN (1972). According to the age estimation for V12-122 and V20-108 (Wollin et al., 1971), the Jamaica episode is dated about $0.19 \mathrm{Ma}$ to $0.175 \mathrm{Ma}$. This date is in good agreement with the age of the Biwa I episode of the $200-\mathrm{m}$ core, which was estimated as about $0.18 \mathrm{Ma}$ by extraporation of three ${ }^{14} \mathrm{C}$ dates and the age of the Blake episode (YASKAWA, 1973), or as $0.17 \mathrm{Ma}$ by fission track dating of the ash BB195 (NISHIMURA and YoKOYAMA, 1975). The age of the other paleomagnetic episodes were also consistent between the deep-sea cores and the 200-m core of Lake Biwa. Therefore, as suggested by NAKAJIMA et al. (1973), it seems possible to correlate the paleomagnetic records of these cores and to assume global occurrence of the reversed polarity episodes in the Brunhes epoch.

The correlation of the reversed polarity episodes between the deep-sea cores and the Lake Biwa core seems inappropriate on a climatostratigraphic basis. While the inferred polarity episodes both from the deep-sea cores (Wollin et al., 1971) and from the 200-m core of Lake Biwa (KAwAI et al., 1972) appeared to have occurred with an approximately $0.1 \mathrm{~m}$.y. interval, phase relations between the paleomagnetic and paleoclimatic changes are contrary in the two records. WoLLIN et al. (1971) showed that horizons of the anomalous inclination zones in V12-122 and RC9-181 were coincident with interglacial intervals indicated by oxygen isotope rations or Globorotalia menardii zonation. On the other hand, KAWAI $(1972,1974)$ pointed out that horizons of the polarity episodes recorded in the Lake Biwa core were sharply coincident with rapid decrease of organic carbon, carbohydrate and protein carbon contents in sediments. Interpreting that the decrease of these materials shows suppression of photo-synthetic reaction, KAWAI $(1972,1974)$ suggested that the polarity episodes occurred during a period of cool climate or on a transitional stage from warm to cool climate.

In the present study, the Biwa I episode was detected at the two areas in central Japan, and then new paleoclimatic information came to light. YoKoYAMA et al. (1977) reported occurrence of Menyanthes trifoliata, a fossil plant indicating cool climate, from the Akatsukikaido Bed of the Takashima Formation. This plant fossil was obtained from the same locality as one of the present sampling sites corresponding to the upper part of the reversed polarity zone (Section A, Fig. 3a). The other record of the Biwa I episode was found in terrace deposits, which are generally believed to be formed in close association with a rise of sea level. It is supposed, however, that the Meimi Gravels at the top of the terrace deposits were formed rather after regression of the sea level. While the 
lower mud of the surveyed section is a marine clay bed (IsHIDA, 1978), the upper mud layers bearing the upper boundary of the Biwa I polarity zone show non-marine facies. It is suggested, therefore, that the Biwa I episode was terminated while the sea level was already falling down. In consideration with the evidence mentioned above, the Biwa I episode is possibly allocated to a transitional stage from an interglacial to a glacial period, which is probably assigned to the Stage 7 to 6 of the oxygen isotope stratigraphy (SHACKLETON and OPDYKE, 1976). This assignment supports the paleoclimatic inference on the Biwa I episode by KAWAI $(1972,1974)$, and is not concordant with that for the Jamaica episode by Wollin et al. (1971).

The discordant paleoclimatic conditions inferred for the Biwa I and Jamaica episode may be removed by considering the timing of remanent magnetization acquisition in sediments. It is now widely accepted that remanent magnetization of sediments is acquired as post-depositional remanent magnetization (post-DRM; IRVING, 1957), which is fixed well after the material was deposited at the sediment/water interface (VEROSUB, 1977). Then, the remanent magnetization observed on a certain horizon of sediments should be regarded as a record of geomagnetic field at somewhat later time than the true accumulation age of the sediments. Although acquisition mechanism of the post-DRM in natural sediments is not quantitatively clarified yet, it is acceptable that in the case of deep-sea sediments with a low sedimentation rate the time-lag between accumulation and magnetization acquisition may be significant as exceeds $10^{4}$ years. NirTsUMA (1977) estimated the depth-lag of paleomagnetic records as about $40 \mathrm{~cm}$ thick in deepsea sediments. Because the sedimentation rate of the deep-sea cores, V12-122, RC9-181 and V20-108 were estimated about 1.2 to $2.4 \mathrm{~cm} / 10^{3}$ years (WoLlIN et al., 1971), the depth-lag of $40 \mathrm{~cm}$ gives a lag in time about $17 \times 10^{3}$ to $33 \times 10^{3}$ years. On the other hand, thickness of $40 \mathrm{~cm}$ in the $200-\mathrm{m}$ core from Lake Biwa corresponds to only about $1 \times 10^{3}$ years. If the depth-lag of post-DRM acquisition such as in the order of $10 \mathrm{~cm}$ is applicable to the deep-sea cores utilized by Wollin et al. (1971), it becomes possible to assume that the geomagnetic polarity episodes recorded in the interglacial zones have actually occurred in later periods, that is, in transitional or glacial stages. Thus, in spite of the apparent discordance of paleoclimatic implications, it is possible to correlate the polarity episodes reported by Wollin et al. (1971) and those found from the 200-m core of Lake Biwa.

Discordance of the climatic conditions on the reversed polarity intervals estimated from the Lake Biwa core and from the deep-sea cores of Wollin et al. (1971) was an obstruction to world-wide correlation of the geomagnetic polarity episodes. The available data, however, does not necessarily prohibit the paleomagnetic correlation between the $200-\mathrm{m}$ core and the deep-sea cores. The Jamaica episode claimed from the Mediterranean, Caribbean and North Pacific Ocean can be assumed correlative with the Biwa I episode, of which occurrence was confirmed in central Japan. This correlation suggests occurrence of a global geomagnetic polarity phenomenon at about 0.17 or $0.18 \mathrm{Ma}$ in the late Brunhes 
epoch.

\section{Conclusive Remarks}

The paleomagnetic study of the parallel sections on land confirmed the occurrence the Biwa I polarity episode in the late Brunhes epoch. This conclusion essentially stands on the stratigraphic correlations of the $200-\mathrm{m}$ core from Lake Biwa and the land sections. The correlation has not been proved as a unique solution, but is acceptable as the most probable interpretation. Therefore, further assessment on this correlation should be made by using other stratigraphical technique, such as direct age determination of the land sections. According to the present conclusion, it appears that the geomagnetic field during the Biwa I episode was shown to have been fully reversed for a certain interval. Further it was suggested that the Jamaica episode, which was inferred from several deepsea cores (Wollin et al., 1971; RYAN, 1972), might correspond to the Biwa I episode. In that case, it is possible to assume that the Biwa I episode was a global geomagnetic features. More detailed geomagnetic behavior, such as secular variations during the episodes and transitional fields at the polarity changes should be revealed in order to understand the nature of short polarity episodes. It is hoped that these future works will be carried out by duplicating the data on tightly correlated parallel sections, as utilized in the present study.

I wish to express my sincere thanks to Professor Sadao Sasajima for his encouragement and extremely valuable advice throughout this work. Thanks are also due to S. Ishida, T. Yokoyama, M. Torii and K. Takemura for their support in the field and laboratory.

\section{REFERENCES}

Creer, K. M., P. W. ReAdman, and A. M. JACobs, Paleomagnetic and paleontological dating of a section at Gioia Tauro, Italy: Identification of the Blake event, Earth Planet. Sci. Lett., 50, 289-300, 1980.

DENHAM, C. R., Blake polarity episode in two cores from the Greater Antiles Outer Ridge, Earth Planet. Sci. Lett., 29, 422-434, 1976.

Denham, C. R., R. F. ANDERSON, and M. P. BACON, Paleomagnetism and radiochemical age estimates for late Brunhes polarity episodes, Earth Planet. Sci. Lett., 35, 384-397, 1977.

Fisher, R. A., Dispersion on a sphere, Proc. Roy. Soc., [A], 217, 295-305, 1953.

HuZiTA, K., T. KASAMA, M. HiRANO, T. ShinodA, and M. TANAKA, Geology and geomorphology of the Rokko area, Kinki district, Japan-with special reference to Quaternary tectonics, $J$. Geosci. Osaka City Univ., 14, 71-124, 1971.

IRVING, E., Origin of the paleomagnetism of the Torridonian sandstones of north-west Scotland, Phil. Trans. R. Soc. London, [A], 250, 100-110, 1957.

ISHIDA, S., The Osaka Group-the cyclic sediments of lacustrine and bay in Plio-Pleistocene, Japan-, Quaternary Res. (Japan), 9, 101-112, 1970.

IsHIDA, S., Problems of the Quaternary strata in Akashi area, in Proc. Kansai Branch Geol. Soc. Japan, 82, 7, 1978.

ITIHARA, M., Some problems of the Quaternary sedimentaries in the Osaka and Akashi areas, Japan, J. Inst. Polytech. Osaka City Univ., [G], 4, 13-40, 1961. 
Itihara, M. and J. OGURo, On the Akashi Group and the Harima Group, Chikyu Kagaku (Earth Sci.), 40, 13-20, 1958.

ItiharA, M., J. OGURo, and H. KinUgasA, On the Akashi Group and the Harima Group (Part 2), J. Geol. Soc. Japan, 66, 605-615, 1960.

KAwaI, N., The magnetic controle on the climate in the geologic time, Proc. Japan Acad., 48, 687-689, 1972.

KAWAI, N., Restrained photosynthesis during Brunhes field transition, Paleolim. Lake Biwa Japanese Pleist., 2, edited by S. Horie, pp. 59-64, 1974.

Kawai, N., K. YASKaWA, T. NAKAJIMA, M. TORII, and S. HoRIE, Oscillating geomagnetic field with a recurring reversal discovered from Lake Biwa, Proc. Japan Acad., 48, 186-190, 1972.

KAWANA, T., Terrace along the middle and lower course of the Kako River, Hyogo Prefecture, Quaternary Res. (Japan), 12, 38-47, 1973.

MAENAKA, K., T. YOKOYAMA, and S. ISHIDA, Paleomagnetic stratigraphy and biostratigraphy of the Plio-Pleistocene in the Kinki district, Japan, Quaternary Res., 7, 341-362, 1977.

NAKajima, T., K. Yaskawa, N. NATSUhara, N. KaWAi, and S. Horie, Very short period geomagnetic excursion 18,000 yr BP., Nature Phys. Sci., 244, 8-10, 1973.

NiITSUMA, N., Zone-magnetization model and depth lag of NRM in deep-sea sediments, Rock Mag. Paleogeophys., 4, edited by M. Kono, pp. 65-71, 1977.

NishimuRA, S. and T. YOKOYAMA, Fission-track ages of volcanic ashes in $200 \mathrm{~m}$ core samples of Laka Biwa, Japan, Proc. Japan Acad., 49, 615-618, 1973.

NishimURA, S. and T. YoKoYAMA, Fission-track ages of volcanic ashes in $200 \mathrm{~m}$ core samples of Lake Biwa and the Kobiwako Group (2), Paleolim. Lake Biwa Japanese Pleist., 3, edited by S. Horie, pp. 138-142, 1975.

RYAN, W. B. F., Stratigraphy of late Quaternary sediments in the eastern Mediterranean, in The Mediterranean Sea: A Natural Sedimentation Laboratory, edited by D. J. Stanley, pp. 149-169, Dowden, Hatchinson and Ross, Stroudsburg, 1972.

SASAJima, S., S. NishimurA, and K. HirooKA, Studies on the Blake episode with special emphasis to east Asian result obtained, Rock Mag. Paleogeophys., 7, edited by M. Kono, pp. 90-93, 1980.

ShACKLETON, N. J. and N. D. OPDYKE, Oxygen-isotope and paleomagnetic stratigraphy of Pacific core V28-239 late Pliocene to latest Pleistocene, Geol. Soc. America Mem., 145, 499-464, 1976.

SMITH, J. D. and J. H. FOSTER, Geomagnetic reversal in Brunhes normal polarity epoch, Science, 163, 565-567, 1969.

Verosub, K. L., Paleomagnetic excursions as magnetostratigraphic horizons: a cautionary note, Science, 190, 48-50, 1975.

Verosub, K. L., Depositional and post depositional process in the magnetization of sediments, Rev. Geophys. Space Phys., 15, 129-143, 1977.

VEROSUB, K. L. and S. K. BANERJEE, Geomagnetic excursions and their paleomagnetic record, Rev. Geophys. Space Phys., 15, 145-155, 1977.

Wollin, G., D. B. Ericson, W. B. F. RYAN, and J. H. Foster, Magnetism of the earth and climatic changes, Earth Planet. Sci. Lett., 12, 175-183, 1971.

YASKAWA, K., Rate of sedimentation for young loose sediment, Rock Mag. Paleogeophys., 1, edited by M. Kono, pp. 39-43, 1973.

YOKOYAMA, T., Tephrochronology and paleogeography of the Plio-Pleistocene in the Eastern Setouchi Geologic Province, southwest Japan, Mem. Fac. Sci., Kyoto Univ., Ser. Geol. Mineral., 36, 19-85, 1969.

Yokoyama, T., Plio-Pleistocene Kobiwako Group in west coast of Lake Biwa with special reference to correlation to 200-m core sample of Lake Biwa by tephra, Paleolim. Lake Biwa Japanese Pleist., 3, edited by S. Horie, pp. 114-137, 1975.

Yokoyama, T., Y. NAKAgAwa, K. TAKemura, and A. HAYAShidA, Some problems on the Middle Pleistocene deduced from sediment core samples from Lake Biwa, central Japan, Quaternary 
Res. (Japan), 19, 185-201, 1980.

Yokoyama, T., Y. Nakagawa, K. Takemura, S. Mori, T. Makinouchi, A. Hayashida, Y. IIDA, and K. MATSUOKA, Stratigraphy of the Takashima Formation of the Plio-Pleistocene Kobiwako Group, Japan, Paleolim. Lake Biwa Japanese Pleist., 7, edited by S. Horie, pp. 100-114, 1979.

Yokoyama, T., K. TAKemuRa, and K. MatsuoKa, Preliminary report on the Takashima Formation, uppermost part of the Kobiwako Group, Plio-Pleistocene sediments around Lake Biwa, Japan, Paleolim. Lake Biwa Japanese Pleist., 5, edited by S. Horie, pp. 54-64, 1977. 